University of Nebraska - Lincoln

DigitalCommons@University of Nebraska - Lincoln

Biological Systems Engineering: Papers and

Publications

Biological Systems Engineering

January 2004

\title{
Residual Effects of Manure and Compost Applications on Corn Production and Soil Properties
}

\author{
Bahman Eghball \\ USDA-ARS \\ Daniel Ginting \\ University of Nebraska-Lincoln, dginting3@unl.edu \\ John E. Gilley \\ University of Nebraska-Lincoln, john.gilley@ars.usda.gov
}

Follow this and additional works at: https://digitalcommons.unl.edu/biosysengfacpub

Part of the Biological Engineering Commons

Eghball, Bahman; Ginting, Daniel; and Gilley, John E., "Residual Effects of Manure and Compost Applications on Corn Production and Soil Properties" (2004). Biological Systems Engineering: Papers and Publications. 14.

https://digitalcommons.unl.edu/biosysengfacpub/14

This Article is brought to you for free and open access by the Biological Systems Engineering at DigitalCommons@University of Nebraska - Lincoln. It has been accepted for inclusion in Biological Systems Engineering: Papers and Publications by an authorized administrator of DigitalCommons@University of Nebraska Lincoln. 


\title{
Residual Effects of Manure and Compost Applications on Corn Production and Soil Properties
}

\author{
Bahman Eghball,* Daniel Ginting, and John E. Gilley
}

\begin{abstract}
Residual effects of manure or compost application on crop production and soil properties can last for several years. This study was conducted to evaluate residual effects of annual or biennial applications of $\mathrm{N}$ - and $\mathrm{P}$-based composted and noncomposted beef cattle (Bos taurus) feedlot manure, chemical fertilizer, and no-treatment check on corn (Zea mays $\mathbf{L}$.) production and soil properties. Manure and compost were applied from 1992 to 1995 , and the residual effects were determined from 1997 to 1999. Residual effects of $\mathrm{N}$ - and $\mathrm{P}$-based manure and compost applications on corn grain yield and $\mathbf{N}$ uptake lasted for at least one growing season while the effects on soil properties were longer lasting. Soil $P$ can contribute to crop $P$ uptake for $>4$ yr after N-based manure or compost application had ceased. The residual effects of manure and compost applications significantly increased soil electrical conductivity and $\mathrm{pH}$ levels and plant-available $\mathrm{P}$ and $\mathrm{NO}_{3}-\mathrm{N}$ concentrations. Four years after the last application, $\mathrm{P}$ leaching to a soil depth of 45 to $60 \mathrm{~cm}$ was observed with $\mathrm{N}$-based manure or compost application. No residual effects of manure and compost applications on soil $\mathrm{NH}_{4}-\mathrm{N}$ were observed. Averaged across years, soil total $\mathbf{C}$ concentrations or quantities were not different among the treatments, indicating that total $\mathrm{C}$ was not a sensitive indicator. Residual effects of $\mathbf{N}$ - or $\mathbf{P}$-based manure or compost application increased crop production for one year and influenced soil properties for several years.
\end{abstract}

\begin{abstract}
$A^{\text {pr }}$ PLICATION OF MANURE or composted manure can result in increased soil concentrations of nutrients and organic matter (Chang et al., 1991; Eghball, 2002). The residual effects of increased nutrients and organic matter in soil following manure or compost application on crop yield and soil properties can last for several years (Mugwira, 1979; Wallingford et al., 1975). Significant residual effects of dairy manure application rates that ranged from 22.5 to $270 \mathrm{Mg}$ dry weight ha ${ }^{-1}$ (530$6400 \mathrm{~kg} \mathrm{~N} \mathrm{ha}^{-1}$ ) on crop yield increase were observed for the higher 180 and $270 \mathrm{Mg} \mathrm{ha}^{-1}$ rates. These high rates also increased $\mathrm{NO}_{3}-\mathrm{N}$ leaching into the soil in a study conducted in Alabama (Mugwira, 1979). Even the lowest application rate of $22.5 \mathrm{Mg} \mathrm{ha}^{-1}$ would have provided nearly twice the $\mathrm{N}$-based requirement for the millet (Pennisetum americanum L.) used (Binford et al., 2000). Four years after application, residual effects of one-time application of beef feedlot manure at rates varying from 123 to $590 \mathrm{Mg}$ dry weight ha ${ }^{-1}$ (1280-6140 $\mathrm{kg} \mathrm{N} \mathrm{ha}{ }^{-1}$ ) resulted in a quadratic increase in corn grain yield but also in increased leaching of $\mathrm{NO}_{3}-\mathrm{N}$ and $\mathrm{Na}$ to a depth of at least $1 \mathrm{~m}$ (Wallingford et al., 1975).
\end{abstract}

B. Eghball and J.E. Gilley, USDA-ARS, 121 Keim Hall, Univ. of Nebraska-Lincoln, Lincoln, NE 68583; and D. Ginting, Dep. of Agron. and Hortic., Univ. of Nebraska-Lincoln, Lincoln, NE 68583. Joint contribution of USDA-ARS and Univ. of Nebraska Agric. Res. Div., Lincoln, NE, as Paper no. 14066. Received 22 Apr. 2003. *Corresponding author (BEGHBALL1@unl.edu).

Published in Agron. J. 96:442-447 (2004)

(c) American Society of Agronomy

677 S. Segoe Rd., Madison, WI 53711 USA
Residual effects of manure or compost application can maintain crop yield level for several years after manure or compost application ceases since only a fraction of the $\mathrm{N}$ and other nutrients in manure or compost become plant available in the first year after application (Motavalli et al., 1989; Eghball et al., 2002). Eghball and Power (1999) found that $40 \%$ of beef cattle feedlot manure $\mathrm{N}$ and $20 \%$ of compost $\mathrm{N}$ were plant available in the first year after application, indicating that about $60 \%$ of manure $\mathrm{N}$ and $80 \%$ of compost $\mathrm{N}$ became plant available in the succeeding years, assuming little or no loss of $\mathrm{N}$ due to $\mathrm{NO}_{3}-\mathrm{N}$ leaching or denitrification.

Residual effects of organic materials on soil properties can contribute to improvement in soil quality for several years after application ceases (Ginting et al., 2003). Increased levels of soil $\mathrm{N}, \mathrm{P}, \mathrm{K}, \mathrm{pH}$, and $\mathrm{C}$ levels in the soil can increase crop yield beyond the application years. Soil $\mathrm{pH}$, organic matter, total $\mathrm{N}, \mathrm{NO}_{3}-\mathrm{N}$, and $\mathrm{P}$ levels were still elevated $4 \mathrm{yr}$ after dairy manure application ceased (Mugwira, 1979; Lund and Doss, 1980). Eghball et al. (2003) found that the increased plant-available $\mathrm{P}$ level in soil following $\mathrm{N}$-based manure or compost application can contribute to crop P uptake for up to $10 \mathrm{yr}$ without any additional $\mathrm{P}$ addition. Ginting et al. (2003) did not find increased emission of greenhouse gasses $\left(\mathrm{CO}_{2}, \mathrm{CH}_{4}\right.$, and $\left.\mathrm{N}_{2} \mathrm{O}\right)$ as a result of residual manure and compost applications that ceased $4 \mathrm{yr}$ earlier.

Residual effects of manure application have been reported for studies where excessive rates of manure had been applied (Wallingford et al., 1975; Mugwira, 1979; Lund and Doss, 1980). Nitrogen- and P-based manure or compost application provides rates that are agronomically and environmentally sound. Nitrogen-based manure or compost application can increase soil P levels (Eghball and Power, 1999). However, in areas where the risk of $\mathrm{P}$ transport in runoff is not a concern, N-based applications can be made. The objective of this study was to determine the residual effects of $\mathrm{N}$ - and P-based manure and composted manure application strategies on corn production and soil properties.

\section{MATERIALS AND METHODS}

\section{Manure or Compost Application}

The experiment was initiated in 1992 on a Sharpsburg silty clay loam soil (fine, smectitic, mesic Typic Argiudolls) under rainfed conditions until 1996 at the University of Nebraska Agricultural Research Center near Mead, NE. The Sharpsburg series consists of deep, moderately well drained soils formed in loess on uplands and high benches. Permeability is moderately slow in the upper part of the soil profile and moderate in the lower part. The study area had a Bray and Kurtz no.1 soil test $\mathrm{P}$ concentration of $69 \mathrm{mg} \mathrm{kg}^{-1}$, a $\mathrm{pH}$ of 6.2 , and a soil

Abbreviation: EC, electrical conductivity. 
Table 1. Composted and noncomposted manure dry weight and $N$ and $P$ applications in 4 yr in eastern Nebraska.

\begin{tabular}{|c|c|c|c|c|c|c|c|c|c|c|c|c|c|c|}
\hline \multirow[b]{2}{*}{ Treatment } & \multicolumn{4}{|c|}{ Dry weight } & \multicolumn{5}{|c|}{ Nitrogen } & \multicolumn{5}{|c|}{ Phosphorus } \\
\hline & 1992 & 1993 & 1994 & 1995 & 1992 & 1993 & 1994 & 1995 & Total & 1992 & 1993 & 1994 & 1995 & Total \\
\hline & \multicolumn{4}{|c|}{$\longrightarrow \mathrm{Mg} \mathrm{ha}^{-1} \longrightarrow$} & \multicolumn{10}{|c|}{$\mathrm{kg} \mathrm{ha}^{-1}$} \\
\hline Manure for $\mathbf{N}$ & 46.9 & 18.5 & 12.1 & 14.5 & 378 & 189 & 189 & 189 & 945 & 107 & 92 & 40 & 46 & 285 \\
\hline Manure for $\mathbf{P}$ & 28.3 & 6.4 & 6.6 & 2.7 & $227(60) \dagger$ & $66(80)$ & 103 (74) & 35 (99) & 744 & 64 & 32 & 21 & $8 \div$ & 125 \\
\hline Manure for N/2 yr & 93.9 & - & 36.3 & - & 756 & - & 567 & - & 1323 & 214 & - & 119 & - & 333 \\
\hline Manure for $P / 2$ yr & 56.4 & - & 19.8 & - & 454 & $-(60)$ & 308 & $-(67)$ & 889 & 129 & - & 64 & - & 193 \\
\hline Compost for $\mathbf{N}$ & 34.6 & 49.5 & 25.1 & 36.4 & 378 & 378 & 189 & 283 & 1228 & 144 & 156 & 102 & 111 & 513 \\
\hline Compost for $\mathbf{P}$ & 15.5 & 10.3 & 5.3 & 2.9 & $168(84)$ & 78 (102) & 40 (111) & $22(123)$ & 728 & 64 & 32 & 21 & $9 \leftarrow$ & 126 \\
\hline Compost for N/2 yr & 69.4 & - & 75.2 & - & 756 & - & 567 & - & 1323 & 289 & - & 305 & - & 594 \\
\hline Compost for $\mathrm{P} / 2$ yr & 31.0 & - & 15.9 & - & 337 (16) & $-(84)$ & $120(94)$ & $-(\mathbf{1 1 0})$ & 761 & 129 & - & 64 & - & 193 \\
\hline Fertilizer & - & - & - & - & 151 & 151 & 151 & 151 & 604 & 26 & 26 & 26 & 26 & 104 \\
\hline Check & $\mathbf{0}$ & $\mathbf{0}$ & $\mathbf{0}$ & $\mathbf{0}$ & $\mathbf{0}$ & $\mathbf{0}$ & $\mathbf{0}$ & $\mathbf{0}$ & $\mathbf{0}$ & $\mathbf{0}$ & $\mathbf{0}$ & $\mathbf{0}$ & $\mathbf{0}$ & $\mathbf{0}$ \\
\hline
\end{tabular}

$\dagger$ Numbers in parentheses are $\mathrm{kg} \mathrm{N} \mathrm{ha}^{-1}$ applied as $\mathrm{NO}_{3} \mathrm{NH}_{4}$ fertilizer.

† Phosphorus application rates for annual P-based manure and compost were about $7 \mathrm{~kg} \mathrm{ha}^{-1}$ less than the expected plant $\mathbf{P}$ uptake (26 kg ha ${ }^{-1}$ ).

organic $\mathrm{C}$ content of $1.8 \mathrm{~g} \mathrm{~kg}^{-1}$ in the top $15 \mathrm{~cm}$ before the initiation of the experiment in 1992.

The experimental design was a randomized complete block with four replications. The 10 treatments applied included annual or biennial manure or compost application based on $\mathrm{N}$ or $\mathrm{P}$ removal by corn $\left(151 \mathrm{~kg} \mathrm{~N} \mathrm{ha}^{-1}\right.$ and $25.8 \mathrm{~kg} \mathrm{P}^{-1}$ for an expected yield level of $9.4 \mathrm{Mg} \mathrm{ha}^{-1}$ ) and fertilized and unfertilized checks (Table 1). Fertilizer was applied in the spring each year from 1993 to 1996. The inorganic fertilizer plots received $\mathrm{N}$ as $\mathrm{NH}_{4} \mathrm{NO}_{3}(34-0-0, \mathrm{~N}-\mathrm{P}-\mathrm{K})$ and $\mathrm{P}$ as superphosphate (0-20-0, N-P-K) in 1993 and diammonium phosphate (18-20-0, N-P-K) in 1994, 1995, and 1996. If necessary, the P-based treatments (annual or biennial application) were supplemented with $\mathrm{N}$ fertilizer as $\mathrm{NH}_{4} \mathrm{NO}_{3}$ in the spring so that a total of $151 \mathrm{~kg} \mathrm{~N} \mathrm{ha}^{-1}$ was available to the crop (Table 1). Biennial manure or compost applications were made to provide $151 \mathrm{~kg} \mathrm{~N} \mathrm{ha}^{-1}$ for $\mathrm{N}$-based and $25.8 \mathrm{~kg} \mathrm{P}^{-1}$ for P-based rates in the second year after application. Nitrogen and $\mathrm{P}$ were overapplied in the first year of application for the biennial manure and compost treatments.

Manure or compost was hand-applied to plots $12.2 \mathrm{~m}$ long and $4.6 \mathrm{~m}$ wide (six corn rows) in late autumn after corn harvest. The $\mathrm{P}$ application rates in $4 \mathrm{yr}$ of applications are given in Table 1. Manure and compost were applied and incorporated into the top $10 \mathrm{~cm}$ soil by disking within $2 \mathrm{~d}$ after application. The experimental area was disked to $10-\mathrm{cm}$ soil depth in the spring before planting. Additional information regarding manure and compost $\mathrm{N}$ and $\mathrm{P}$ availability assumptions, corn yield, $\mathrm{N}$ and $\mathrm{P}$ uptake, and soil properties during the application years from 1993 to 1996 is reported in Eghball and Power (1999) and Eghball (2002).

\section{Residual Effects}

For the 1997, 1998, and 1999 growing seasons, no manure, compost, or fertilizer (except $\mathrm{N}$ application for the fertilizer treatment only in 1999) was applied. The experiment was under linear-move pivot sprinkler irrigation from 1997 to 1999. The amount of water applied was $30.7 \mathrm{~cm}$ in 1997, $8.9 \mathrm{~cm}$ in 1998 , and $17.0 \mathrm{~cm}$ in 1999 . Lower amount of irrigation water was applied in 1998 than the other years because of a problem with the pivot system early in the growing season. In all $7 \mathrm{yr}$, corn (Pioneer brand hybrid '3394') was planted at a rate of 47000 seeds $\mathrm{ha}^{-1}$ at a row spacing of $0.76 \mathrm{~m}$. Weed control was achieved by band application of herbicide in the corn rows at planting and by cultivation. Four randomly chosen plants were harvested at tasseling for plant biomass and $\mathrm{N}$ content measurements in 1997 and 1998. The middle two rows of corn (6.1 m long) were harvested, and grain yield was measured. Stover was harvested from one row $6.1 \mathrm{~m}$ long. Grain yields were adjusted to a water content of $155 \mathrm{~g} \mathrm{~kg}^{-1}$, and stover yield is reported on oven-dry $\left(60^{\circ} \mathrm{C}\right)$-weight basis. Plots were harvested on 7 Oct. 1997 and 1998 and on 8 Sept. 1999.

Soil samples at depth increments of 0 to 15,15 to 30,30 to 45,45 to 60 , and 60 to $90 \mathrm{~cm}$ were collected from all plots shortly after corn harvest in the autumn. Soil samples were air-dried, ground to pass a 1-mm sieve, and analyzed for selected soil parameters. Soil $\mathrm{pH}$ and electrical conductivity (EC) were determined on 1:1 soil/water ratio (Smith and Doran, 1996). Plant and soil total $\mathrm{N}$ and $\mathrm{C}$ were determined by dry combustion as reported by Schepers et al. (1989). Soil bulk density on this site was not significantly influenced by the 10 treatments used in the application years (Eghball, 2002). Therefore, soil bulk density from 1996 was used to calculate the total $\mathrm{N}$ and $\mathrm{C}$ quantities for each plot. Soil $\mathrm{NO}_{3}-\mathrm{N}$ and $\mathrm{NH}_{4}-\mathrm{N}$ concentrations were determined on samples extracted by $\mathrm{KCl}$ and using a Lachat system (Zellweger Analytics, Milwaukee, WI). Phosphorus was analyzed by the Bray and Kurtz no. 1 soil $\mathrm{P}$ test method.

Analysis of variance was used to determine differences among treatments across years using SAS PROC MIXED procedure (Littell et al., 1996). In these analyses, year and soil depth increments were considered repeated observations. A probability level $\leq 0.05$ was considered significant.

\section{RESULTS AND DISCUSSION}

\section{Biomass and Nitrogen Uptake at Tasseling}

Plant weight at tasseling in 1997 was significantly greater for the annual P-based manure, $\mathrm{N}$ - and P-based compost, and commercial fertilizer treatments than those for the check plots (Table 2). The biennial manure or compost application did not result in greater biomass than the check plots (Table 2) as the last biennial applications were made in the autumn of 1994 for the 1995 and 1996 corn growing seasons. The last application time for the annual manure, compost, and fertilizer treatments was in the autumn of 1995 for 1996 corn growing season. These data indicate that the positive residual effects of $\mathrm{N}$ - and P-based manure and compost applications and $\mathrm{N}$ fertilizer on plant biomass at tasseling were still evident for one growing season after the intended crop. By 1998, however, the residual effects of manure, compost, and fertilizer applications did not increase plant biomass at tasseling even though plant $\mathrm{N}$ content was higher for the biennial P-based manure treatment than the check (Table 2). Plant $\mathrm{N}$ uptake in 1997, in general, followed a pattern similar to that for plant biomass (Table 2). 
Table 2. Residual effects of beef cattle manure or composted manure application on plant weight and $\mathrm{N}$ uptake at tasseling in $2 \mathrm{yr}$ in eastern Nebraska.

\begin{tabular}{|c|c|c|c|c|}
\hline \multirow[b]{2}{*}{ Treatment $\dagger$} & \multicolumn{2}{|c|}{ Dry matter } & \multicolumn{2}{|c|}{$N$ content } \\
\hline & 1997 & 1998 & 1997 & 1998 \\
\hline & & $-\mathbf{g} \mathbf{p}$ & & \\
\hline Manure for $\mathbf{N}$ & 143 & 126 & 1.92 & 1.33 \\
\hline Manure for $\mathbf{P}$ & 163 & 118 & 2.29 & 1.13 \\
\hline Manure for $N / 2 y$ & 149 & 129 & 2.09 & 1.39 \\
\hline Manure for $P / 2 y$ & 154 & 140 & 2.23 & 1.57 \\
\hline Compost for $\mathbf{N}$ & 161 & 126 & 2.25 & 1.37 \\
\hline Compost for $\mathbf{P}$ & 167 & 130 & 2.33 & 1.35 \\
\hline Compost for $N / 2 y$ & 149 & 141 & 2.06 & 1.50 \\
\hline Compost for $P / 2 y$ & 157 & 122 & 2.13 & 1.21 \\
\hline Fertilizer & 164 & 121 & 2.39 & 1.34 \\
\hline Check & 136 & 116 & 1.59 & 1.19 \\
\hline $\mathbf{L S D}_{0.05}$ & 22 & NS§ & 0.61 & $\mathbf{0 . 3 5}$ \\
\hline $\mathrm{CV}, \%$ & 12.0 & 20.9 & 22.1 & 23.7 \\
\hline
\end{tabular}

$\dagger \mathbf{N}$ and $\mathbf{P}$ indicate applications to meet $\mathbf{N}$ or $\mathbf{P}$ needs of corn, respectively, and $2 y$ indicates biennial application. Manure and compost were applied from 1992 to 1995.

$\leftarrow$ In 1999 only, $\mathbf{N}$ was applied to the fertilizer treatment only at a rate of $151 \mathrm{~kg} \mathrm{ha}^{-1}$.

$\S \mathbf{N S}=$ nonsignificant.

\section{Grain and Stover Yields and Total Nitrogen Uptake}

Residual effects of annual or biennial N- or P-based manure, compost, and fertilizer treatments resulted in greater grain yield than the check plots in 1997 (Table 3). The biennial treatments had similar plant biomass to the check plots at tasseling (Table 2), but by harvest time, manure and compost treatments resulted in greater grain yield than the check treatment (Table 3 ). It seems that $\mathrm{N}$ mineralization after tasseling contributed to increased yield for the biennial applications even though the applications were made about 3 yr earlier (Eghball, 2000). By 1998, all treatments, except biennial P-based manure, had grain yields similar to the check plots (Table 3). Lower grain yield in 1998 than the other years reflects less irrigation water applied in 1998. In 1999, when only the fertilizer treatment received $\mathrm{NH}_{4} \mathrm{NO}_{3}$, greater grain yield was found for the fertilizer than other treatments except the biennial N-based compost treat-

Table 3. Residual effects of beef cattle manure or composted manure application on corn grain yield, stover yield, and total $\mathbf{N}$ uptake in three years in eastern Nebraska.

\begin{tabular}{|c|c|c|c|c|c|c|c|c|c|}
\hline \multirow[b]{2}{*}{ Treatment $\dagger$} & \multicolumn{3}{|c|}{ Grain yield $\ddagger$} & \multicolumn{3}{|c|}{ Stover yield } & \multicolumn{3}{|c|}{ Total N uptake } \\
\hline & 1997 & 1998 & 1999 & 1997 & 1998 & 1999 & 1997 & 1998 & 1999 \\
\hline & \multicolumn{6}{|c|}{ - Mg ha ${ }^{-1}$} & \multicolumn{3}{|c|}{$-\mathrm{kg} \mathrm{ha}^{-1}$} \\
\hline e for $\mathbf{N}$ & 9.49 & 6.58 & 9.30 & 6.62 & & 5. & 161 & 109 & 157 \\
\hline & 9.50 & 6.1 & & & & & 171 & & 148 \\
\hline & 9.88 & 6.81 & 9.00 & 6.77 & 3.55 & 5.66 & 184 & 107 & 147 \\
\hline & 9.92 & 7.03 & 9.22 & 5.86 & 4.13 & 5.70 & 172 & 114 & 158 \\
\hline & 9.87 & 6.73 & 8.9 & 6.59 & 3.66 & 5.65 & 167 & 102 & 146 \\
\hline & 10.25 & 6.62 & 9.40 & 6.95 & 3.82 & 5.17 & 186 & 100 & 151 \\
\hline $\mathbf{N} / 2 y$ & 10.20 & 6.73 & 9.73 & 6.56 & 3.85 & 5.40 & 178 & 106 & 159 \\
\hline or $\mathbf{P} / 2 \mathbf{y}$ & 9.57 & 6.01 & 9.44 & 6.36 & 3.60 & 6.26 & 166 & 87 & 153 \\
\hline Fer & 9.90 & 6.58 & 10.64 & 5.91 & 4.24 & 6.71 & 178 & 113 & 184 \\
\hline & 7.08 & 5.63 & 8.85 & 5.54 & 3.41 & 5.29 & 108 & 91 & 142 \\
\hline & 0.97 & 1.25 & 0.94 & 1.11 & 0.78 & 1.09 & 23 & 26 & 19 \\
\hline $\mathrm{CV}, \%$ & 13.5 & 14.6 & 9.4 & 12.9 & 16.8 & 16.5 & 16.4 & 17.8 & 11.9 \\
\hline
\end{tabular}

$\dagger \mathbf{N}$ and $\mathbf{P}$ indicate applications to meet $\mathbf{N}$ or $\mathbf{P}$ needs of corn, respectively, and $2 y$ indicates biennial application. Manure and compost were applied from 1992 to 1995 .

+ Grain yield at $155 \mathrm{~g} \mathrm{~kg}^{-1}$ water content.

$\S$ In 1999 only, $\mathbf{N}$ was applied to the fertilizer treatment only at a rate of 151 kg ha ${ }^{-1}$.

ment. Residual effects of manure treatments resulted in corn grain yields that were 85 to $89 \%$ of that for the applied $\mathrm{N}$ fertilizer treatment while they were 84 to $89 \%$ for the compost treatments in 1999 (Table 3). The check plot produced a corn yield of $8.85 \mathrm{Mg} \mathrm{ha}^{-1}\left(141 \mathrm{bu} \mathrm{ac}^{-1}\right)$ in 1999 even though it had not received any treatment since 1992. The higher organic matter in this Mollisol $(\approx 3.5 \%)$ seemed to have contributed enough $\mathrm{N}$ to produce $8.85 \mathrm{Mg} \mathrm{ha}^{-1}$ corn yield, which was $83 \%$ of that for the applied fertilizer treatment.

Stover yield was not different among most of the treatments in 1997 (Table 3). It seems that higher corn yields resulting from the residual effects of manure, compost, and $\mathrm{N}$ fertilizer did not result in greater stover yields than the check, except biennial N-based manure and annual P-based compost treatments. In 1998 and 1999, only the fertilizer treatment produced greater amount of stover than the check plots (Table 3). The fertilizer treatment received $\mathrm{N}$ fertilizer in 1999 and was expected to have greater stover yield than the check treatment. Averaged across treatments, stover/grain yield ratio was 0.67 in 1997, 0.58 in 1998, and 0.60 in 1999. There was damage from corn rootworm (Diabrotica barberi) in 1998, and that might have contributed to reduced grain and stover yields.

Total $\mathrm{N}$ uptakes for all treatments were greater than the check plots in 1997 (Table 3). By 1998, however, all treatments had total $\mathrm{N}$ uptake similar to the check plots. As expected, the fertilizer treatment resulted in greater $\mathrm{N}$ uptake than the check plots in 1999 (Table 3).

\section{Soil Properties}

Averaged across treatments, soil surface (0 to $15 \mathrm{~cm}$ ) pH decreased from 1997 to 1999 (Table 4). Eghball (1999)

Table 4. Residual effects of beef cattle manure or composted manure application on soil electrical conductivity (EC), $\mathbf{p H}$, total $C$ and $N$ concentrations, and quantities at $0-$ to $15-\mathrm{cm}$ soil depth in eastern Nebraska.

\begin{tabular}{|c|c|c|c|c|c|c|}
\hline Variable & EC & pH & Total C & Total N & Total C & Total N \\
\hline & \multicolumn{2}{|l|}{ dS $\mathbf{m}^{-1}$} & \multicolumn{2}{|c|}{$\longrightarrow \mathrm{g} \mathrm{kg}^{-1}-$} & \multicolumn{2}{|c|}{$-\operatorname{Mg~ha}^{-1}$} \\
\hline \multicolumn{7}{|l|}{ Year } \\
\hline 1997 & 0.263 & 6.58 & 20.7 & 1.83 & 40.29 & 3.55 \\
\hline 1998 & 0.340 & 6.43 & 21.1 & 1.86 & 41.03 & 3.61 \\
\hline 1999 & 0.334 & 6.30 & 20.3 & 1.81 & 39.34 & 3.49 \\
\hline $\mathbf{L S D}_{0.05}$ & 0.011 & & 0.4 & & 0.81 & 0.08 \\
\hline \multicolumn{7}{|l|}{ Treatment $\dagger$} \\
\hline Manure for $\mathbf{N}$ & 0.323 & 6.50 & 21.6 & 1.89 & 39.75 & 3.48 \\
\hline & 0.287 & & 19.7 & & 37.49 & 3.29 \\
\hline for $N / 2 y$ & 0.323 & & 21.3 & 1.9 & 40.41 & 3.60 \\
\hline Manure for $P / 2 y$ & 0.318 & 6.40 & 22.2 & 1.97 & 43.56 & 3.85 \\
\hline Compost for $\mathbf{N}$ & 0.357 & 6.75 & 21.0 & 1.88 & 41.20 & 3.70 \\
\hline Compost for $\mathbf{P}$ & 0.299 & 6.33 & 19.9 & 1.76 & 41.30 & 3.61 \\
\hline Compost for $N / 2 y$ & 0.353 & 6.70 & 22.2 & 2.05 & 41.68 & 3.84 \\
\hline Compost for $P / 2 y$ & 0.296 & 6.35 & 20.1 & 1.78 & 39.20 & 3.46 \\
\hline Fertilizer & 0.277 & 6.02 & 19.9 & 1.71 & 39.94 & 3.43 \\
\hline Check & 0.294 & 6.43 & 19.3 & 1.66 & 37.67 & 3.23 \\
\hline $\mathbf{L S D}_{0.05}$ & 0.026 & 0.17 & NS\$ & 0.24 & NS & NS \\
\hline \multicolumn{7}{|l|}{ Analysis of variance } \\
\hline Year & 0.0001 & 0.000 & 0.0003 & 0.0573 & 0.0005 & 0.0197 \\
\hline Treatment & 0.0001 & 0.000 & 0.5524 & & 0.9810 & 0.8114 \\
\hline Year $\times$ treatment & 0.2456 & 0.6177 & 0.4559 & 0.3078 & 0.5192 & 0.2468 \\
\hline \multicolumn{7}{|c|}{$\begin{array}{l}\uparrow N \text { and } P \text { indicate applications to meet } N \text { or } P \text { needs of corn, respectively, } \\
\text { and } 2 y \text { indicates biennial application. Manure and compost were applied } \\
\text { from } 1992 \text { to } 1995 \text {. } \\
+ \text { In } 1999 \text { only, } N \text { was applied to the fertilizer treatment only at a rate of } \\
151 \mathrm{~kg} \mathrm{ha}^{-1} \text {. } \\
\S \mathrm{NS}=\text { nonsignificant. }\end{array}$} \\
\hline
\end{tabular}


found that manure and composted manure provide a liming effect on soil since the cattle diet contains lime, which is subsequently excreted in manure. The liming effect seems to diminish with time after termination of manure and compost applications. There was a liming effect with both manure and compost when compared with commercial fertilizer application (Table 4). Across $3 \mathrm{yr}$, the N-based application of manure or compost resulted in higher soil surface $\mathrm{pH}$ than the P-based treatments, indicating the combination effects of greater liming influence of higher application rates associated with $\mathrm{N}$-based treatments and the acidifying effect of supplemental commercial fertilizer added with the P-based treatments (Table 1). Soil surface EC was also higher for the residual effect of N-based than the P-based manure and compost applications (Table 4). The higher EC for the N-based treatments reflects the larger amounts of manure and compost applied.

Total $\mathrm{C}$ and $\mathrm{N}$ concentrations and quantities in the 0to $15-\mathrm{cm}$ soil were highest in 1998 and decreased in 1999 (Table 4). There were residual effects of manure and compost applications on soil $\mathrm{N}$ concentration $(P=0.0507$; Table 4). The biennial N-based compost and P-based manure treatments had more soil $\mathrm{N}$ content than the check or the fertilizer treatments. The residual effects of annual N- or P-based treatments were not different from those of the fertilizer or check treatments. Total $\mathrm{C}$ and $\mathrm{N}$ quantities were not different among treatments, indicating that total $\mathrm{C}$ and $\mathrm{N}$ were not sensitive indicators of the $\mathrm{C}$ and $\mathrm{N}$ pools in this high organic matter Mollisol beyond the application years. However, Ginting et al. (2003) showed that $4 \mathrm{yr}$ after applications had ceased, soil potentially mineralizable $\mathrm{N}$ and microbial biomass $\mathrm{C}$ were greater for manure and compost applications than those for the control or inorganic fertilizer treatment.

Similar to the 0 - to $15-\mathrm{cm}$ soil depth, $\mathrm{pH}$ in the 15 to 30-cm soil depth decreased with time when averaged across all treatments (Table 5). No residual effects of the treatments on $\mathrm{EC}, \mathrm{pH}$, and total $\mathrm{C}$ and $\mathrm{N}$ concentrations and quantities were observed in the $15-$ to $30-\mathrm{cm}$ soil depth (Table 5). Manure was incorporated into the top $10 \mathrm{~cm}$ of soil, and it appears that the movement of salt, lime, $\mathrm{C}$, and $\mathrm{N}$ did not occur to the $15-$ to $30-\mathrm{cm}$ soil depth. During the application years (1992-1995), no difference among the treatments for soil properties was observed, except EC, at the 15- to 30-cm soil depth increment (Eghball, 2002).

Soil $\mathrm{NO}_{3}-\mathrm{N}$ and $\mathrm{NH}_{4}-\mathrm{N}$ concentrations were different among the soil depth increments, with the concentrations being generally higher in the surface $15 \mathrm{~cm}$ than deeper soil increments (Table 6). Across soil depths, $\mathrm{NO}_{3}-\mathrm{N}$ concentrations after corn harvest were higher for the annual N-based manure, biennial P-based manure, and biennial N-based compost treatments than the check plots (Table 6). By 1999, the fertilizer treatment, which received $\mathrm{NH}_{4} \mathrm{NO}_{3}$ fertilizer, had higher $\mathrm{NO}_{3}-\mathrm{N}$ concentration than the other treatments. Soil $\mathrm{NH}_{4}-\mathrm{N}$ concentrations were similar among treatments in all three residual years. Residual values of manure and compost application resulted in increased soil $\mathrm{NO}_{3}-\mathrm{N}$ for $3 \mathrm{yr}$.
Table 5. Residual effects of beef cattle manure or composted manure application on soil electrical conductivity (EC), pH, total $\mathrm{C}$ and $\mathbf{N}$ concentrations and quantities at $15-$ to $30-\mathrm{cm}$ soil depth in eastern Nebraska.

\begin{tabular}{|c|c|c|c|c|c|c|}
\hline Variable & EC & pH & Total C & Total N & Total C & Total N \\
\hline & $\mathrm{dS} \mathbf{m}^{-1}$ & & $\mathrm{~g} \mathrm{k}_{\mathrm{k}}$ & $\alpha^{-1}$ & - Mg & -1 \\
\hline \multicolumn{7}{|l|}{ Year } \\
\hline 1997 & 0.233 & 6.44 & 19.4 & 1.58 & 41.17 & 3.34 \\
\hline 1998 & 0.340 & 6.38 & 18.7 & 1.58 & 39.81 & 3.35 \\
\hline 1999 & 0.262 & & 19.0 & 1.60 & 40.38 & 3.39 \\
\hline $\mathbf{L S D}_{0.05}$ & 0.013 & 0.04 & 0.5 & $\mathbf{N S} \dagger$ & 1.04 & NS \\
\hline \multicolumn{7}{|l|}{ Treatment $t$} \\
\hline Manure for $\mathbf{N}$ & 0.272 & 6.33 & 19.3 & 1.59 & 40.78 & 3.37 \\
\hline & 267 & & & 1.56 & $\mathbf{3 8 . 5 0}$ & 3.23 \\
\hline Man & 0.285 & 6.3 & 18.8 & 1.60 & 39.31 & 3.35 \\
\hline & 0.283 & & 0.6 & 1.67 & 43.51 & 3.54 \\
\hline & 0.285 & 6.59 & 17.6 & 1.52 & 36.81 & 3.17 \\
\hline & 0.279 & & & 1.5 & 41.13 & 3.38 \\
\hline & 0.301 & & & 1.6 & 42.18 & 3.52 \\
\hline & 0.260 & 6.3 & 9.0 & 1.5 & 41.77 & 3.39 \\
\hline & 0.283 & 6.34 & 9.4 & 1.59 & 40.65 & 3.34 \\
\hline Check & 0.268 & 6.36 & 19.2 & 1.60 & 39.82 & 3.31 \\
\hline $\mathbf{L S D}_{0.05}$ & NS & NS & NS & NS & NS & NS \\
\hline \multicolumn{7}{|l|}{ Analysis of variance } \\
\hline Year & 0.00 & 00 & 0.0058 & & .0384 & 0.473 \\
\hline & 0.3151 & & 0.8867 & & 0.9544 & \\
\hline Year $\times$ treatment & 0.7365 & 0.2947 & 0.6546 & 0.9765 & 0.6936 & 0.9567 \\
\hline
\end{tabular}

$\dagger \mathbf{N S}=$ nonsignificant.

$\mp \mathbf{N}$ and $\mathbf{P}$ indicate applications to meet $\mathbf{N}$ or $\mathbf{P}$ needs of corn, respectively, and $2 y$ indicates biennial application. Manure and compost were applied from 1992 to 1995 .

$\S$ In 1999 only, N was applied to the fertilizer treatment only at a rate of 151 $\mathrm{kg} \mathrm{ha}^{-1}$.

Soil test P levels from 1996 to 1999 in the 0- to 15 and $15-$ to $30-\mathrm{cm}$ soil depth increments were reported by Eghball et al. (2003). Soil test P levels in 1999 (Table 7) can be used to determine $\mathrm{P}$ leaching $4 \mathrm{yr}$ after manure

Table 6. Residual effects of beef cattle manure or composted manure application on soil nitrate and ammonium concentrations in eastern Nebraska.

\begin{tabular}{|c|c|c|c|c|c|c|}
\hline \multirow[b]{2}{*}{ Variable } & \multicolumn{2}{|c|}{1997} & \multicolumn{2}{|c|}{1998} & \multicolumn{2}{|c|}{1999} \\
\hline & $\mathrm{NO}_{3}-\mathrm{N}$ & $\mathbf{N H}_{4}-\mathbf{N}$ & $\mathrm{NO}_{3}-\mathrm{N}$ & $\mathbf{N H}_{4}-\mathbf{N}$ & $\mathbf{N O}_{3}-\mathbf{N}$ & $\mathbf{N H}_{4}-\mathbf{N}$ \\
\hline & & & - mg l & $\mathbf{k g}^{-1}$ & & \\
\hline \multicolumn{7}{|l|}{ Depth (m) } \\
\hline $0.00-0.15$ & 1.72 & 2.32 & 3.09 & 2.59 & 5.64 & 1.51 \\
\hline $0.15-0.30$ & 1.47 & 1.88 & 4.71 & 1.94 & 2.23 & 1.29 \\
\hline $0.30-0.60$ & 1.90 & 1.38 & 1.47 & 1.50 & 1.28 & 1.12 \\
\hline $0.60-0.90$ & 1.16 & 1.42 & - & - & 0.63 & 1.36 \\
\hline $0.90-1.20$ & - & - & - & - & 0.85 & 2.02 \\
\hline $\mathbf{L S D}_{0.05}$ & 0.28 & 0.29 & 0.59 & 0.29 & 0.41 & 0.13 \\
\hline \multicolumn{7}{|l|}{ Treatment $\uparrow$} \\
\hline Manure for $\mathbf{N}$ & 1.92 & 1.59 & 4.00 & 2.05 & 1.53 & 1.38 \\
\hline Manure for P & 1.37 & 1.81 & 2.43 & 2.18 & 1.87 & 1.53 \\
\hline Manure for $N / 2 y$ & 1.92 & 1.74 & 3.39 & 2.02 & 1.89 & 1.61 \\
\hline Manure for $P / 2 y$ & 2.71 & 1.79 & 3.65 & 2.05 & 1.80 & 1.34 \\
\hline Compost for $\mathbf{N}$ & 0.88 & 1.61 & 2.97 & 1.66 & 2.01 & 1.20 \\
\hline Compost for $\mathbf{P}$ & 1.18 & 1.66 & 2.64 & 2.09 & 1.78 & 1.51 \\
\hline Compost for $N / 2 y$ & 2.38 & 1.82 & 4.79 & 2.09 & 2.49 & 1.30 \\
\hline Compost for $P / 2 y$ & 1.20 & 1.89 & 2.38 & 2.21 & 1.44 & 1.55 \\
\hline Fertilizert & 1.44 & 1.79 & 2.77 & 2.04 & 3.70 & 1.31 \\
\hline Check & 0.61 & 1.81 & 1.90 & 1.73 & 1.36 & 1.33 \\
\hline $\mathbf{L S D}_{0.05}$ & 1.21 & NS§ & 1.74 & NS & 1.18 & NS \\
\hline \multicolumn{7}{|l|}{ Analysis of variance } \\
\hline Depth & 0.0001 & 0.0001 & 0.0001 & 0.0001 & 0.0001 & 0.0001 \\
\hline Treatment & 0.0307 & 0.9647 & 0.0637 & 0.6287 & 0.0165 & 0.9913 \\
\hline Depth $\times$ treatment & 0.1180 & 0.9981 & 0.9246 & 0.8939 & 0.5264 & 0.9567 \\
\hline
\end{tabular}

$\dagger \mathbf{N}$ and $\mathbf{P}$ indicate applications to meet $\mathbf{N}$ or $\mathbf{P}$ needs of corn, respectively, and $2 y$ indicates biennial application. Manure and compost were applied from 1992 to 1995.

$\$$ In 1999 only, $N$ was applied to the fertilizer treatment only at a rate of 151 kg ha ${ }^{-1}$.

$\S$ NS = nonsignificant. 
Table 7. Residual effects of beef cattle manure or composted manure application on soil test $P$ (Bray and Kurtz no. 1) at various depth increments in 1999 in eastern Nebraska.

\begin{tabular}{|c|c|c|c|c|c|}
\hline \multirow[b]{2}{*}{ Treatment $\dagger$} & \multicolumn{5}{|c|}{ Soil depth (cm) } \\
\hline & 0-15 & $15-30$ & $30-45$ & $45-60$ & $60-90$ \\
\hline & \multicolumn{5}{|c|}{ - $\mathbf{m g ~ k g}^{-1}$} \\
\hline Manure for $\mathbf{N}$ & 77.5 & 22.0 & 11.8 & 10.2 & 23.9 \\
\hline Manure for $\mathbf{P}$ & $\mathbf{5 0 . 3}$ & 21.4 & 11.8 & 8.8 & 15.9 \\
\hline Manure for $N / 2 y$ & 90.7 & 34.0 & 13.5 & 8.9 & 18.8 \\
\hline Manure for $P / 2 y$ & 69.7 & 21.5 & 12.1 & 6.9 & 12.9 \\
\hline Compost for $\mathbf{N}$ & 109.1 & 34.8 & 14.2 & 10.6 & 20.0 \\
\hline Compost for $\mathbf{P}$ & 58.0 & 24.4 & 11.9 & 8.8 & 22.1 \\
\hline Compost for $N / 2 y$ & 167.6 & 49.7 & 18.3 & 9.0 & 19.1 \\
\hline Compost for $P / 2 y$ & 58.2 & 42.3 & 12.0 & 6.9 & 15.5 \\
\hline Fertilizer & 55.1 & 19.5 & 9.7 & 6.3 & 13.7 \\
\hline Check & 49.2 & 27.1 & 11.0 & 7.3 & $\mathbf{1 7 . 8}$ \\
\hline $\mathbf{L S D}_{0.05}$ & 25.9 & 17.5 & 3.0 & 3.1 & NS§ \\
\hline
\end{tabular}

$\dagger \mathbf{N}$ and $P$ indicate applications to meet $N$ or $P$ needs of corn, respectively, and $2 y$ indicates biennial application. Manure and compost were applied from 1992 to 1995.

$†$ In 1999 only, $\mathbf{N}$ was applied to the fertilizer treatment only at a rate of $151 \mathrm{~kg} \mathrm{ha}^{-1}$.

$\S \mathbf{N S}=$ nonsignificant.

or compost application had ceased. Soil P levels in 1999 were different among treatments in all soil depth increments except in the 60- to $90-\mathrm{cm}$ depth increment (Table 7). This indicates leaching of $\mathrm{P}$ from applied manure and compost to the $45-$ to $60-\mathrm{cm}$ soil depth increment. Eghball (2003) showed P leaching to the soil depth increment of 15 to $30 \mathrm{~cm}$ in 1996 when manure or compost application ceased. By 1999, however, P had leached deeper into the soil. In the $0-$ to $15-\mathrm{cm}$ soil depth increment, the N-based treatments had higher soil P levels than the check, fertilizer, and P-based treatments (Table 7). At the $45-$ to $60-\mathrm{cm}$ soil depth increment, annual N-based manure and compost applications had greater soil $\mathrm{P}$ levels than the fertilizer treatment. The biennial N-based compost treatment had higher soil $\mathrm{P}$ levels than the fertilizer or check treatments in the 15- to 30- and 30- to $45-\mathrm{cm}$ soil depth increments. A greater amount of $\mathrm{P}$ was applied for the biennial $\mathrm{N}$-based compost treatment (Table 1), resulting in deeper leaching of $\mathrm{P}$ in the soil profile. The amount of $\mathrm{P}$ applied was higher for the $\mathrm{N}$-based compost than manure treatments since only $20 \%$ of compost $\mathrm{N}$ was considered plant available in the first year after application compared with $40 \%$ for noncomposted manure when applications were made.

The elevated plant available $\mathrm{P}$ concentration in the soil surface ( 0 to $15 \mathrm{~cm}$ ) as a result of manure or compost application can remain for several years. This has both agronomic and environmental implications since it can contribute to crop $\mathrm{P}$ uptake and also can be available for transport by runoff. Eghball et al. (2003) found that $10 \mathrm{yr}$ of crop removal was needed to reduce soil P level from $265 \mathrm{mg} \mathrm{kg}^{-1}$ to the original $69 \mathrm{mg} \mathrm{kg}^{-1}$ that existed before compost application. How long soil $\mathrm{P}$ continues to contribute to crop $P$ uptake depends on soil characteristics. Sharpley (1996) found that the rate of $\mathrm{P}$ release from high-P soils decreased more rapidly as soil $\mathrm{P}$ sorption saturation increased and $\mathrm{P}$ sorption maxima decreased. Even though positive residual effects of manure or compost application on crop production were observed for at least $1 \mathrm{yr}, \mathrm{P}$ contribution to plant uptake could last much longer than $1 \mathrm{yr}$. That can be significant in soils that are entirely $\mathrm{P}$ deficient or have P-deficient areas within the field.

\section{CONCLUSIONS}

Residual effects of $\mathrm{N}$ - and P-based manure and compost applications on corn yield and $\mathrm{N}$ uptake can last for at least one growing season. Residual effects of N-based manure and compost applications on corn production were greater than the P-based treatments since the amounts of manure or compost applied were greater for $\mathrm{N}$ - than P-based management systems. Residual effects of manure and compost applications on soil properties were longer lasting than those influencing corn production. Soil $\mathrm{P}, \mathrm{NO}_{3}-\mathrm{N}, \mathrm{EC}$, and $\mathrm{pH}$ levels were greater for the N-based manure or compost application than the check treatment $4 \mathrm{yr}$ after the last applications were made. Phosphorus leaching to a soil depth increment of 15 to $30 \mathrm{~cm}$ was observed in 1996, $1 \mathrm{yr}$ after the last manure and compost applications. By 1999 however, P from N-based manure or compost treatments had leached to the $45-$ to $60-\mathrm{cm}$ soil depth increment. Leached $\mathrm{P}$ can reach the ground water when ground water is close to the soil surface or excess $\mathrm{P}$ is in soils with fluctuating ground water. Both corn production and soil properties were improved by the residual values of applied manure or compost. Phosphorus-based application was environmentally sound since it provided nutrients for the crop while maintaining the soil $\mathrm{P}$ level similar to the untreated check. Applications of manure and compost not only improved soil properties for several years after applications had ceased but also provided nutrients and liming effects for the growing corn.

\section{REFERENCES}

Binford, G.D., G.W. Hergert, and J.M. Blumenthal. 2000. Millet. p. 135-137. In R.B. Ferguson and K.M. De Groot (ed.) Nutrient management for agronomic crops in Nebraska. Univ. of Nebraska Coop. Ext., Lincoln.

Chang, C., T.G. Sommerfeldt, and T. Entz. 1991. Soil chemistry after eleven annual applications of cattle feedlot manure. J. Environ. Qual. 20:475-480.

Eghball, B. 1999. Liming effects of beef cattle feedlot manure or compost. Commun. Soil Sci. Plant Anal. 30:2563-2570.

Eghball, B. 2000. Nitrogen mineralization from field-applied beef cattle feedlot manure or compost. Soil Sci. Soc. Am. J. 64:2024-2030.

Eghball, B. 2002. Soil properties as influenced by phosphorus- and nitrogen-based manure and compost applications. Agron. J. 94: 128-135.

Eghball, B. 2003. Leaching of phosphorus fractions following manure and compost applications. Commun. Soil Sci. Plant Anal. 34:2803-2815.

Eghball, B., and J.F. Power. 1999. Phosphorus and nitrogen-based manure and compost application: Corn production and soil phosphorus. Soil Sci. Soc. Am. J. 63:895-901.

Eghball, B., J.F. Shanahan, G.E. Varvel, and J.E. Gilley. 2003. Reduction of high soil test phosphorus by corn and soybean varieties. Agron. J. 95:1233-1239.

Eghball, B., B.J. Wienhold, J.E. Gilley, and R.A. Eigenberg. 2002. Mineralization of manure nutrients. J. Soil Water Conserv. 57: 470-473.

Ginting, D., A. Kessavalou, B. Eghball, and J.W. Doran. 2003. Greenhouse gas emissions and soil indicators four years after manure and compost applications. J. Environ. Qual. 32:23-32.

Littell, R.C., G.A. Milliken, W.W. Stroup, and R.D. Wolfinger. 1996. SAS system for mixed models. SAS Inst., Cary, NC. 
Lund, Z.F., and B.D. Doss. 1980. Residual effects of dairy cattle manure on plant growth and soil properties. Agron. J. 72:123-130.

Motavalli, P.P., K.A. Kelling, and J.C. Converse. 1989. First-year nutrient availability from injected dairy manure. J. Environ. Qual. 18: 180-185.

Mugwira, L.M. 1979. Residual effects of dairy manure on millet and rye forage and soil properties. J. Environ. Qual. 8:251-255.

Schepers, J.S., D.D. Francis, and M.T. Thompson. 1989. Simultaneous determination of total $\mathrm{C}$, total $\mathrm{N}$, and ${ }^{15} \mathrm{~N}$ on soil and plant material. Commun. Soil Sci. Plant Anal. 20:949-959.
Sharpley, A.N. 1996. Availability of residual phosphorus in manured soils. Soil Sci. Soc. Am. J. 60:1459-1466.

Smith, J.L., and J.W. Doran. 1996. Measurement and use of $\mathrm{pH}$ and electrical conductivity for soil quality analysis. p. 169-185. In J.W. Doran and A.J. Jones (ed.) Methods of assessing soil quality. SSSA Spec. Publ. 49. SSSA, Madison, WI.

Wallingford, G.W., L.S. Murphy, W.L. Powers, and H.L. Manges. 1975. Disposal of beef-feedlot manure: Effects of residual and yearly applications on corn and soil chemical properties. J. Environ. Qual. 4:526-531. 